\title{
Transmitter Concentration at a Three-Dimensional Synapse
}

\author{
RUKMINI RAO-MIROTZNIK, ${ }^{2}$ GERSHON BUCHSBAUM, ${ }^{2}$ AND PETER STERLING ${ }^{1}$ \\ ${ }^{1}$ Department of Neuroscience and ${ }^{2}$ Department of Bioengineering, University of Pennsylvania, Philadelphia, \\ Pennsylvania 19104
}

\begin{abstract}
Rao-Mirotznik, Rukmini, Gershon Buchsbaum, and Peter Sterling. Transmitter concentration at a three-dimensional synapse. J. Neurophysiol. 80: 3163-3172, 1998. At intensities from starlight to 1000 -fold brighter, the mammalian rod synapse transmits a binary signal, the capture of 0 or 1 photon. Zero is signified by tonic exocytosis, and 1 is signified by a brief pause. The synapse is three dimensional: vesicles discharge at the apex of a deep cleft created by the invagination of four postsynaptic processes. Two horizontal cell spines bearing $\alpha$-amino-3-hydroxy-5-methyl-4-isoxazolepropionic acid (AMPA) receptors reach near to the release sites (16 $\mathrm{nm}$ ), and two bipolar dendrites bearing mGluR6 receptors end far from the release sites (up to $640 \mathrm{~nm}$ ). We considered two hypotheses for signal transfer: transmitter quanta might be integrated in the cleft and sensed as a steady concentration (high for 0 and low for 1); or quanta might be sensed at the postsynaptic membrane as discrete postsynaptic potentials (PSPs) and integrated within the dendrite. We calculate from a passive diffusion model that the invagination empties rapidly $(\tau \sim 1.7 \mathrm{~ms})$. Further calculations suggest that a glutamate concentration high enough to hold a bipolar cell in darkness at one end of its response range would require $\sim 4,000$ vesicles/s. On the other hand, the glutamate pulse from a single vesicle would reach both nearby AMPA receptors (low affinity) and distant mGluR6 receptors (high affinity) at spatiotemporal concentrations matched to their apparent binding affinities. Thus one vesicle could evoke a discrete PSP in all four postsynaptic processes. We calculate from a stochastic model that PSPs could transfer the binary signal at $\sim 100$ vesicles/s. Thus dendritic integration of unitary PSPs is both plausible and 40-fold more efficient than the alternative mechanism. The rod's deep invagination, rather than serving to pool transmitter, may serve to prevent "spillover" of transmitter to neighboring rods. Spillover, by pooling the noise from neighboring rods, would impair transmission of their binary signals.
\end{abstract}

INTRODUCTION

A synapse in the CNS is typically two dimensional: a discoid active zone discharges transmitter quanta across a 20-nm cleft toward a discoid patch of receptors. But the ribbon synapse of a vertebrate photoreceptor is three dimensional: a linear active zone discharges transmitter quanta at the apex of a deep, three-dimensional cleft (Fig. 1) (e.g., Dowling and Boycott 1966; Rao-Mirotznik et al. 1995). The cleft is created by two horizontal cell spines that invaginate the synaptic terminal to reach near the vesicle release sites $(16 \mathrm{~nm})$ and by bipolar cell dendrites that also invaginate but end far from the release sites (up to $640 \mathrm{~nm}$ in cat). Vesicles discharge tonically in darkness, and the signal is

The costs of publication of this article were defrayed in part by the payment of page charges. The article must therefore be hereby marked "advertisement" in accordance with 18 U.S.C. Section 1734 solely to indicate this fact. transferred when light, hyperpolarizing the terminal, interrupts the vesicle stream (Dowling 1987). We asked how the invagination's three-dimensional structure would affect transfer of the visual signal.

One idea is that glutamate diffuses slowly from the invagination and thus accumulates at physiological concentrations during tonic release (Fig. 1, $C$ and $E$ ). When light suppresses release, glutamate is removed rapidly from the cleft by a transporter, and this fall in concentration is detected postsynaptically. This hypothesis was proposed to explain why blocking the glutamate transporter rapidly eliminates the horizontal cell light response (Eliasof and Werblin 1993). The hypothesis is novel in that transmitter quanta are integrated within the cleft and sensed, not as discrete events, but as a concentration. Another idea is that vesicles simply cause discrete PSPs which are integrated within the postsynaptic neuron (Fig. 1D) (Rao et al. 1994). Although this hypothesis is utterly familiar, the unusually great distance from release site to bipolar dendrite raises some doubt that the glutamate pulse from one vesicle could evoke a postsynaptic potential (PSP).

To evaluate these hypotheses, we considered the synaptic terminal of the mammalian rod. At intensities from starlight to 1,000-fold brighter, this synapse reliably transmits an irreducibly simple signal, i.e., a binary signal, representing 0 or 1 photon per integration time (reviewed by Rao et al. 1994; Sterling 1998; van Rossum and Smith 1998). The glutamate concentrations effective for both types of postsynaptic neuron are known (see next section). Therefore the computations are constrained by known levels of performance. Furthermore the synaptic structure has been quantified for cat: a single active zone (130 release sites) discharges into the deepest known invagination (Rao-Mirotznik et al. 1995). Therefore passive efflux from the invagination should be slowest of any photoreceptor, and a glutamate pulse reaching the bipolar dendrite should be the most spatially and temporally smeared. Thus compared with other photoreceptor synapses, the rod terminal's geometry should be most favorable to integration within the cleft and least favorable to integration within the dendrite.

We calculate that the invagination empties rapidly and that to maintain a steady physiological concentration of glutamate would require tonic release on the order of 4,000 vesicles/s. We also calculate that a single vesicle can deliver a strong enough glutamate pulse to evoke a PSP at the distant bipolar dendrites and that the tonic rate of PSPs needed to transmit the rod's binary signal would be on the order of 100 vesicles/active zone/s. This approximates the rate measured for the salamander rod for calcium concentrations corresponding to the dark level (see Rieke and Schwartz 1996; 

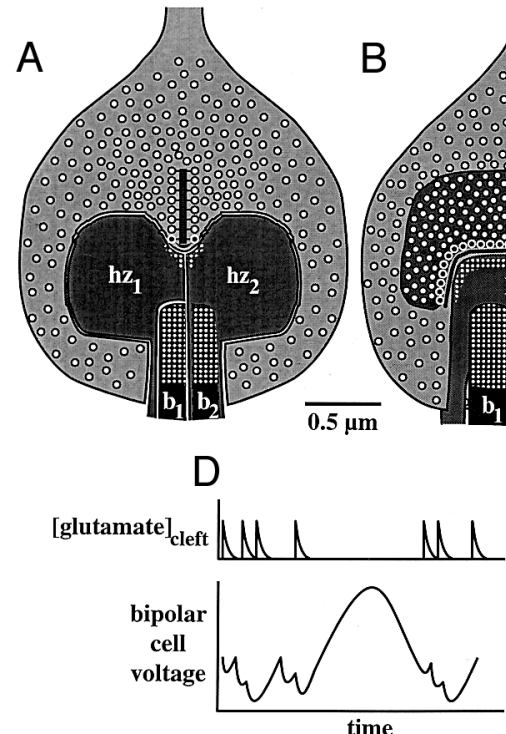

B
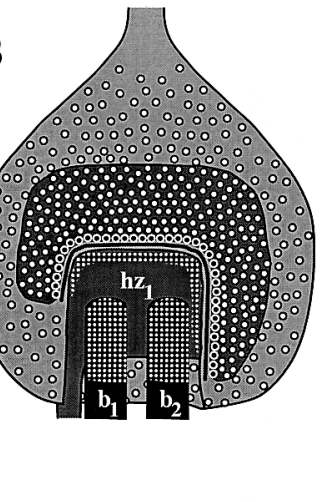

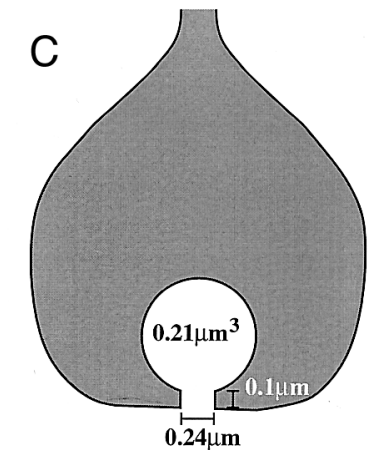

E

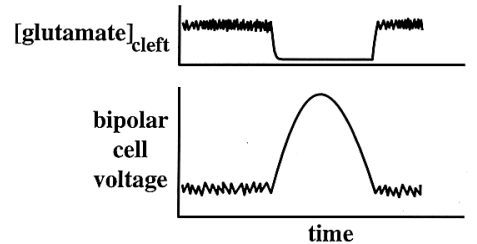

FIG. 1. Top: key architectural features of mammalian rod synapse. $A$ and $B$ : orthogonal views based on 3-dimensional reconstruction (Rao-Mirotznik et al. 1995). A: synaptic vesicles at the basal edge of the ribbon (dark circles outlined in white) contact release sites at the active zone. Single vesicle discharges glutamate near to low-affinity receptors on horizontal cells $\left(h z_{1}, \mathrm{hz}_{2}\right)$ but far $(130-640 \mathrm{~nm})$ from high-affinity receptors on bipolar cells $\left(b_{1}, \mathrm{~b}_{2}\right) . B$ : 1-dimensional active zone (denoted by row of white outlined vesicles) arches over the bipolar dendrites, providing 130 release sites. Two-dimensional ribbon is extensive, tethering 640 additional vesicles. $C$ : invagination includes a large extracellular volume of $0.21 \mu \mathrm{m}^{3}$ that empties through a short neck the extracellular space of which forms a disk of $0.12 \mu \mathrm{m}$ radius. Bottom: alternative hypotheses of function. $D$ : dendritic integration of unitary postsynaptic potentials (PSPs): standing concentration of glutamate in the cleft is low; glutamate pulse due to vesicle discharge raises this concentration sharply, evoking a PSP. The bipolar cell integrates PSPs from 20 rods to produce a fluctuating hyperpolarization. One photon suppresses release long enough that the bipolar cell depolarizes and releases transmitter at its own terminal (Rao et al. 1994). E: extracellular integration of vesicle discharge: standing concentration of glutamate in the invagination is higher, enough to steadily activate receptors. Postsynaptic fluctuations are finer grained, corresponding to channel fluctuations rather than to unitary PSPs (clusters of active channels).

Townes-Anderson et al. 1985). Thus the second hypothesis (dendritic integration of quantal PSPs) seems favored-not beyond a reasonable doubt - but certainly by a preponderance of the evidence.

\section{RESULTS}

\section{Diffusion of glutamate from the invagination is rapid}

Our calculations assume that a rod synaptic vesicle contains 2,000 molecules of glutamate. This value lies within a range derived from our own measurements of vesicles tethered on the synaptic ribbon $(28 \pm 6 \mathrm{~nm}$, inner diameter mean $\pm \mathrm{SD})$ and from reported concentrations of intravesicular glutamate (60-210 mM) (Burger et al. 1989; Nicholls and Attwell 1990; Riveros et al. 1986).

Two thousand glutamate molecules dissolved in the invagination's extracellular volume $\left(\sim 0.21 \mu \mathrm{m}^{3}\right)$ (Rao-Mirotznik et al. 1995) give a concentration of $16 \mu \mathrm{M}$. But the enclosed volume empties via a wide neck of extracellular space (Fig. 1C), and efflux from the invagination is rapid. For this reduced geometry and, assuming a uniform concentration within the sphere and zero concentration outside, Almers et al. (1989) give the time constant of emptying as

$$
\tau=\frac{V_{\text {invag }}}{D}\left(\frac{l+\frac{\pi a}{2}}{\pi a^{2}}\right)
$$

where: $V_{\text {invag }}=$ volume of invagination, $D=$ diffusion coef- ficient, $l=$ neck length, and $a=$ effective neck radius. With $D=8 \times 10^{-6} \mathrm{~cm}^{2} / \mathrm{s}$ (Hille 1992), $l=0.1 \mu \mathrm{m}$, and $a=$ $0.12 \mu \mathrm{m}$, the time constant of emptying is $1.7 \mathrm{~ms}$. Thus compared with the rod response ( $\sim 200 \mathrm{~ms}$ ) (Baylor et al. 1984), diffusion out of the invagination should be rapid and not much retarded by the neck. This calculation agrees with a similar one for the kinetics of transmitter efflux from the invagination of the goldfish cone terminal (Vandenbranden et al. 1996). The diffusion constant $(D)$ used here was for $25^{\circ} \mathrm{C}$. At mammalian body temperature $\left(\sim 37^{\circ} \mathrm{C}\right), D$ would be greater by $\sim 1.5$-fold (Hille 1992) and emptying would be slightly faster.

\section{Release rate needed for integration within the cleft}

We then wished to calculate the rate of vesicle release needed to maintain glutamate in the invagination at a concentration appropriate to the dark. At this concentration, most channels at the dendritic tip should be closed, holding the bipolar dendrite near its maximal response level (Ashmore and Falk 1980). Then a pause in release (due to a photon) would plunge the glutamate concentration toward the low level outside the invagination, allowing the synapse to use the full dynamic range for signal transfer. The rod bipolar cell, both in mammal and in dogfish, responds maximally at $100 \mu \mathrm{M}$ glutamate (de la Villa et al. 1995; Shiells and Falk 1994). Therefore we calculated what minimum release rate (ignoring stochastic fluctuations) would be needed to 
hold cleft glutamate at this level. The flux out of the invagination is given by (Hille 1992)

$$
\phi=\frac{\pi a^{2} D C_{\text {invag }}}{l+\frac{\pi a}{2}}
$$

With a glutamate concentration $\left(C_{\text {invag }}\right)$ of $100 \mu \mathrm{M}$, efflux from the invagination would be $\sim 7.5 \times 10^{6}$ molecules/s. To sustain this concentration would require an equivalent inflow, amounting to the glutamate from $\sim 4,000$ vesicles/s.

This calculation assumes that a vesicle contains 2,000 glutamate molecules. A lower rate would require both vesicle diameter and intravesicular concentration to be at their estimated maxima. Thus a 34-nm vesicle containing $210 \mathrm{mM}$ glutamate would hold 2,600 molecules, and the calculated release rate could relax to 3,000/s. However, if the number of glutamate molecules per vesicle was smaller, say 700 (26-nm vesicle at $130 \mathrm{mM}$ glutamate), the calculated rate would be $>4,000 / \mathrm{s}$. Yet even this small glutamate pulse from one vesicle could evoke PSPs (see next section). Thus the choice of 2,000 glutamate molecules/vesicle seems fair to both hypotheses for transferring the binary signal.

The preceding calculations omit an explicit term for the glutamate transporter. The transporter must play some essential role because blocking it rapidly abolishes synaptic transmission from photoreceptor to horizontal cell (Eliasof and Werblin 1993; Vandenbranden et al. 1996). Information about the location, densities, and kinetics of transporters at the mammalian rod terminal is still too sparse for their inclusion in a quantitative model. However, transporters located within the invagination (on the rod and/or the invaginating processes) with kinetics and densities comparable to the bipolar cell's glutamate receptor would tend to oppose the effect of vesicular release, requiring still higher rates than we have calculated here to maintain a steady concentration of glutamate. But a transporter at the mouth of the invagination, or just outside, would serve to maintain the sharp gradient essential to passive efflux. If the transporters at these loci were blocked, their binding sites would quickly saturate and efflux from the invagination would decline. Thus the transporter has a key role in our passive model, but it is an implicit one-to maintain the gradient (see DISCUSSION).

\section{Could each vesicle evoke a discrete PSP?}

We turned to the alternative hypothesis, that each vesicle evokes a discrete PSP. This would require the glutamate pulse to rise high enough for long enough to modulate on the order of 10 cation channels. Thus we developed a model of the rod invagination to calculate the spatiotemporal glutamate concentration due to a single vesicle and to evaluate whether $\sim 10$ channels per postsynaptic process could be activated.

The choice of 10 for the number of postsynaptic channels per process is justified as follows. It fits (roundly) the report of de la Villa et al. (1995) that an isolated cat rod bipolar cell contains $\sim 125$ cation channels (13-pS unitary conductance) gated by glutamate. With 20 rods/bipolar cell (Sterling et al. 1988), there would be about six channels per synapse. Because these channels are gated indirectly via $G$ protein,
A

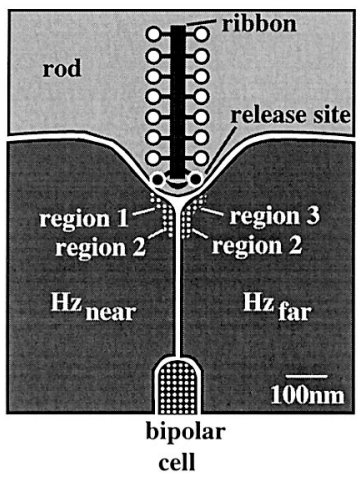

C

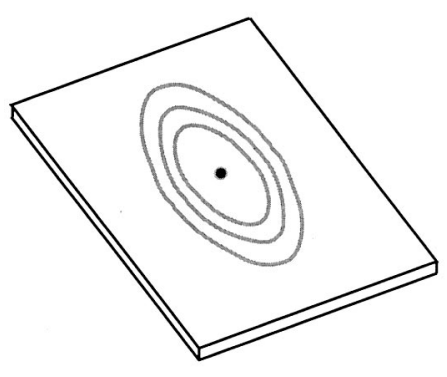

B

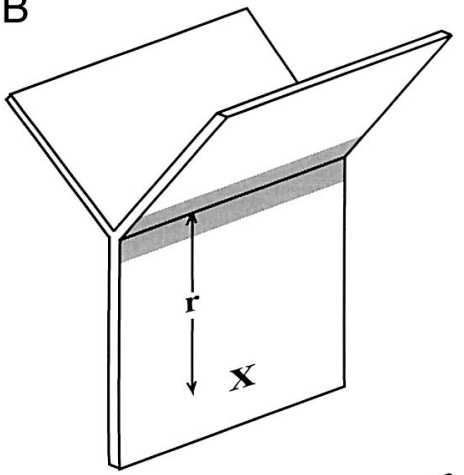

D

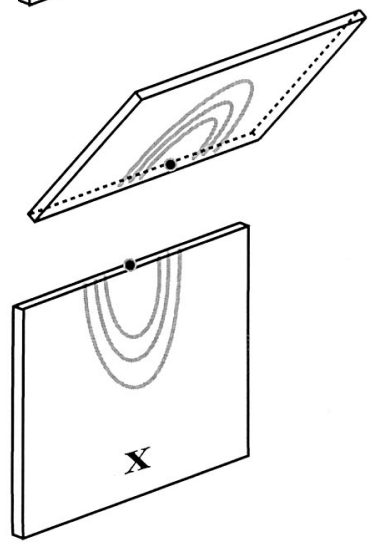

FIG. 2. Model for transmitter diffusion. A: rod synapse at high magnification. Horizontal cell receptors (speckling) lie directly across from a release site but also extend perpendicular to this plane of section, i.e., parallel to the linear active zone (Fig. 1B). Bipolar cell receptors (speckling), lie far from the release site but distribute over entire dendritic tip (Vardi and Morigiwa 1997). $B$ : extracellular space was modeled as 3 intersecting slabs. Shading indicates location of horizontal cell receptors; $X$ indicates location of bipolar dendrite at a distance $r$ from the vesicle discharge site. $C$ : concentration at horizontal cell receptors in region 1 was calculated using an instantaneous point source (central spot) on an infinite plane. $D$ : concentration at horizontal receptors in regions 2 and 3 and at bipolar cell receptors were calculated using a point source at the edge of a semi-infinite plane.

$\sim 10$ channels would be modulated by a smaller number of mGluR6 receptors (Nawy and Jahr 1990; Shiells and Falk 1990). Other small central neurons commonly are reported to express $\sim 10$ receptor-gated ion channels per synapse (e.g., Edwards et al. 1990; Hestrin 1992; Stern et al. 1992; Traynelis et al. 1993). And, although cultured neurons may express higher numbers (e.g., Forti et al. 1997; Frerking et al. 1995), it seemed reasonable to use values from freshly dissociated bipolar neurons and small neurons in brain slices.

\section{Diffusion model of the synapse}

A synaptic vesicle at the rod active zone empties into a large invagination housing four postsynaptic processes: two horizontal cell terminals and two bipolar cell dendrites (Fig. $1, A$ and $B)$. The extracellular space between these processes forms a Y, shown in a cut perpendicular to the ribbon (Fig. $2 A$ ). To calculate the spatiotemporal concentration of glutamate in the cleft ([glutamate $]_{\text {cleft }}$ ), we modeled the $\mathrm{Y}$ as confluent slab-like channels, $120^{\circ}$ apart and $16 \mathrm{~nm}$ wide (Fig. 2B). The width was determined from tissue fixed conventionally with aldehydes and osmium (Rao-Mirotznik et 
al. 1995), but it agrees with measurements from tissue subjected to rapid freezing under high pressure (Wilson and Karwoski, First International Workshop on Müller cells, Leipzig 1995) and also with physiological measurements (Karwoski et al. 1984). The active zone was the line along the confluence of the two arms, and single vesicles were discharged anywhere along this line. Each discharge was treated initially as an instantaneous point source and later as a prolonged source.

HORIZONTAL CELL RECEPTORS. A vesicle discharge first encounters horizontal cell spines which express the GluR2/3 subunit [ $\alpha$-amino-3-hydroxy-5-methyl-4-isoxazolepropionic acid (AMPA)] of the ligand-gated GluR receptor family (Morigiwa and Vardi 1998). We assumed a receptor density of $5,000 / \mu \mathrm{m}^{2}$, corresponding to intramembrane particles in freeze fracture images (Raviola and Gilula 1975), an $\mathrm{EC}_{50}$ of $0.5 \mathrm{mM}$, and a Hill coefficient of 2 (Patneau and Mayer 1990; Trussell and Fischbach 1989; Ueda and Kaneko, unpublished observations). Receptor desensitization has not been measured for AMPA receptors on mammalian rod horizontal cells. We omitted densitization because, for AMPA receptors on the catfish cone horizontal cell, densitization is slow $(\sim 1 \mathrm{~ms})$ compared with the calculated time course of the glutamate pulse (see Eliasof and Jahr 1997). Although a train of quanta directed at a patch of receptors might desensitize them, quanta are released stochastically from 130 sites along the 2,300-nm length of the active zone (Fig. $1 B$ ). Therefore successive quanta rarely will hit the same patch of receptors. Furthermore, the dark-adapted L-HC horizontal cell of Xenopus gives sustained responses to glutamate, so rod-driven AMPA receptors may resist desensitization (Krizaj et al. 1994).

Although the receptors are quite near the release site, they encompass a range of distances, so we divided the receptor sheet into three regions (Fig. 2A). The minimum distance from release site to region 1 was $\sim 16 \mathrm{~nm}$, and to regions 2 and 3 it was $\sim 50 \mathrm{~nm}$. Because vesicle discharge is not exactly at the intersection of the clefts but at a short distance into region 1 , to calculate [glutamate] cleft for the strip of receptors in this region, the cleft was treated as an infinite slab and vesicle discharge as a point source of 2,000 molecules at the center (Fig. $2 C$ ). We assume that half of these 2,000 molecules diffuse toward the intersection of the clefts, and once there, diffuse equally into the two remaining clefts. Thus for regions 2 and 3, the cleft was considered a semiinfinite slab with a point source at one edge of 500 molecules (Fig. 2D).

BIPOLAR CELL RECEPTORS. The glutamate molecules next encounter the tips of bipolar dendrites that express mGluR6 receptors (Nomura et al. 1994; Vardi and Morigiwa 1997). We assumed the same receptor density as for the horizontal cells but took a much lower $\mathrm{EC}_{50}(10 \mu \mathrm{M})$ (de la Villa et al. 1995) and a Hill coefficient of 1 or 2 (Shiells and Falk 1994; Tian and Slaughter 1994). These receptors lie quite far from the release site, $130-640 \mathrm{~nm}$ (Fig. 1, $A$ and $B$ ) (Rao-Mirotznik et al. 1995). To calculate [glutamate $]_{\text {cleft }}$ for these receptors, the central cleft was treated as a semi-infinite slab with a point source at one edge (lower slab, Fig. 2D). Because $\sim 10$ horizontal cell receptors would have bound glutamate in the central cleft (see Glutamate pulse at the horizontal cell rises high and falls fast), the strength of this point source would be 480 molecules.

THE COMPUTATIONS. We solved the diffusion equation for an infinite slab with no flux through the walls and with an instantaneous point source to obtain

$$
C(r, t)=\frac{B C_{\mathrm{o}}}{4 \pi D t w} e^{-r^{2} / 4 D t} \sum_{\mathrm{n}=-\infty}^{\infty} \cos \left(\frac{2 n \pi z}{w}\right) e^{-D t(2 n \pi / w)^{2}}
$$

where: $C=$ glutamate concentration $=[\text { glutamate }]_{\text {cleft }}, r=$ distance from point source, $t=$ time after release, $C_{\mathrm{o}}=$ strength of point source in number of glutamate molecules, $B=1,000 / 6 \times 10^{23}=$ conversion factor to get molarity, $D=$ diffusion coefficient, $w=$ slab width, and $z=$ location across slab width. A diffusion coefficient $(D)$ of $8 \times 10^{-6}$ $\mathrm{cm}^{2} / \mathrm{s}$ (Hille 1992) and a synaptic cleft width $(w)$ of $16 \mathrm{~nm}$ reduces $E q .3$ to the solution for a point source on an infinite plane (Crank 1990). This value of $D$ is for $25^{\circ} \mathrm{C}$ (Longsworth 1953); $D$ adjusted for $37^{\circ} \mathrm{C}$ (Wahl et al. 1996) gives similar results. Incorporating the background glutamate concentration $\left(C_{\mathrm{i}}\right)$ of $\sim 1 \mu \mathrm{M}$ (Nicholls and Attwell 1990) then gives

$$
C_{\text {infinite }}(r, t)=\frac{B C_{\mathrm{o} \text { infinite }}}{4 \pi D t w} e^{-r^{2} / 4 D t}+C_{\mathrm{i}}
$$

The glutamate concentration due to a point source at the edge of a semi-infinite slab can be approximated as twice Eq. 3 (Crank 1990) so

$$
C_{\text {semi-infinite }}(r, t)=\frac{B C_{\text {o semi-infinite }}}{2 \pi D t w} e^{-r^{2} / 4 D t}+C_{\mathrm{i}}
$$

Taking the derivative of Eqs. 4 and 5 with respect to $t$, setting them equal zero and solving for $t$ give the times to peak $\left(t_{\text {peak }}\right)$ for the infinite and semi-infinite case, respectively, as a function of distance, $r$. Substituting $t_{\text {peak }}$ back into the appropriate concentration equations gives the peak concentrations as a function of $r$ for each case.

\section{Glutamate pulse at the horizontal cell rises high and falls fast}

The [glutamate $]_{\text {cleft }}$ would rise above $0.5 \mathrm{mM}$ for region 1 as far as $220 \mathrm{~nm}$ from the release site and for regions 2 and 3 as far as $160 \mathrm{~nm}$ (Fig. $3 A$ ). So 88 receptors in region 1 and 64 receptors each in regions 2 and 3 see [glutamate $]_{\text {cleft }}>\mathrm{EC}_{50}$. These concentrations are reached very rapidly $(<20 \mu \mathrm{s})$, but the number of receptors bound depends on how long the concentrations are sustained.

For receptors in region 1 , calculated [glutamate $]_{\text {cleft }}$ decays rapidly (Fig. $3 B$ ). The temporal profiles vary with distance from release site, but for distances out to $220 \mathrm{~nm}$ and for times $>100 \mu$ s the profiles converge. Thus regardless of distance, the concentration remains $>0.1 \mathrm{mM}$ for $\sim 200$ $\mu$ s. Profiles calculated for regions 2 and 3 are similar: the concentration remains $>0.1 \mathrm{mM}$ for $\sim 100 \mu$ s (curves not shown). From these spatiotemporal concentrations, we calculated the binding to AMPA receptors. Binding of receptor sites is described by

$$
\frac{\partial}{\partial t} \text { bound sites }=\mathrm{ON} \text { rate } \times[\text { glutamate }] \times \text { total sites }
$$$$
\text { - OFF rate } \times \text { bound sites }
$$ 

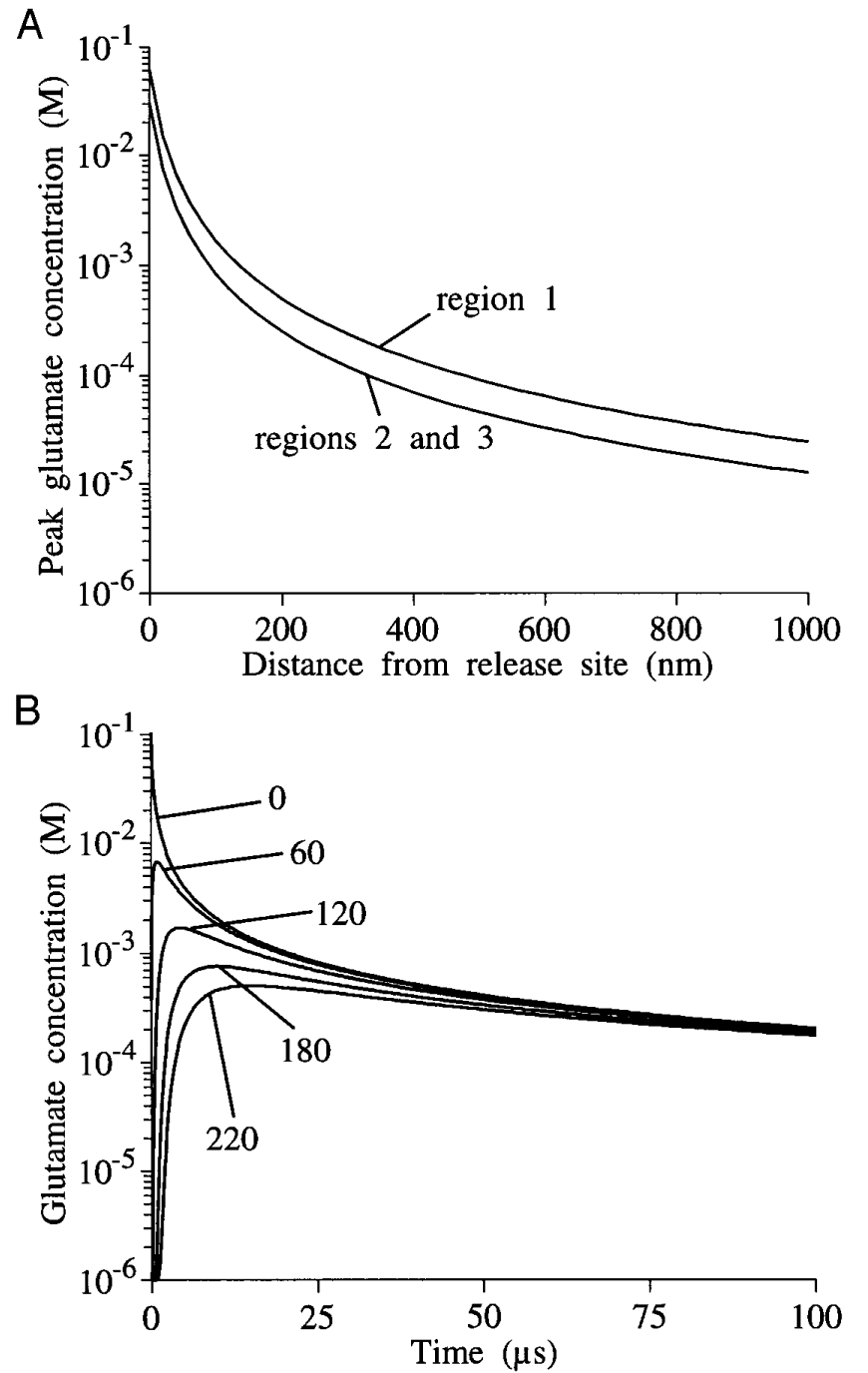

FIG. 3. Glutamate concentration from 1 vesicle discharge peaks high at horizontal cell receptors and falls fast. $A$ : peak glutamate concentrations for the $\alpha$-amino-3-hydroxy-5-methyl-4-isoxazolepropionic acid (AMPA) receptors in regions 1-3 (defined in Fig. 2A) fall off with distance from the release site: receptors within $220 \mathrm{~nm}$ in region 1 and within $160 \mathrm{~nm}$ in regions 2 and 3 see concentrations above the horizontal cell receptor $\mathrm{EC}_{50}$ $(0.5 \mathrm{mM}) . B$ : glutamate concentrations for the receptors in region 1 that see concentrations above the $\mathrm{EC}_{50}$ peak in $<20 \mu \mathrm{s}$.

where the ON and OFF rates are the association and dissociation rate constants, respectively. We assume that few receptors are bound immediately following release, so the second term is negligible. Then approximating [glutamate] as $C_{\mathrm{a}}$ and integrating over time from zero to $t_{C \geq C \mathrm{Ca}}$, the time for which the concentration remains above $C_{\mathrm{a}}$ (taken in this case as $0.1 \mathrm{mM})$, gives

$$
\text { fraction bound sites }=\mathrm{ON} \text { rate } \times C_{\mathrm{a}} \times t_{C \geq C_{\mathrm{a}}}
$$

The square of Eq. 7 gives the fraction of receptors doubly bound. The horizontal cell that does not directly face the releasing site sees lower glutamate concentrations. For 10 of its receptors to bind doubly, about five should bind doubly in regions 2 and 3; thus the fraction of receptors doubly bound would be $5 / 64$ per region. From Eq. 7 this requires ON rates of $\sim 30 \cdot \mu \mathrm{M}^{-1} \cdot \mathrm{s}^{-1}$. With this on rate, the hori- zontal cell directly facing the releasing site would doubly bind $\sim 40$ receptors.

Because this oN rate seems eminently plausible (see next section ), we conclude that the spatiotemporal [glutamate $]_{\text {cleft }}$ following release of one vesicle could doubly bind $\geq 10$ receptors on each horizontal cell process. Moreover concentration profiles similar to the present ones, when analyzed by AMPA receptor kinetic schemes, show substantial receptor binding (Holmes 1995). Our conclusion that a vesicle can evoke a discrete PSP in the horizontal cell is no surprise because the synaptic cleft geometry is conventional. But a conclusion that the same vesicle can evoke a PSP at a distant bipolar dendrite would be somewhat startling.

\section{Glutamate "puff" at the bipolar cell peaks low and falls slowly}

With about a quarter of the glutamate molecules diffusing past the horizontal cells into the stem of the $\mathrm{Y}$, the peak [glutamate $]_{\text {cleft }}$ at the bipolar dendrites would reach 30-700 $\mu \mathrm{M}$ (Fig. 4). Given the bipolar cell's dose-response range of $1-100 \mu \mathrm{M}$ (de la Villa et al. 1995), these concentrations could evoke a bipolar cell response. The rise and decay times are slow, so [glutamate] $]_{\text {cleft }}$ remains $>10 \mu \mathrm{M}$ for $\sim 1 \mathrm{~ms}$. Furthermore, by $0.5 \mathrm{~ms}$, the concentrations due to various release sites (130-640 nm away) converge and decay slowly in concert. Consequently, the fourfold range of distances from release site to dendrite would hardly matter.

To doubly bind 10 receptors on the patch of bipolar dendrite nearest to the release site (taken as $5 \%$ of the $1 \mu \mathrm{m}^{2}$ invaginating process) would require an ON rate of $\sim 20 \cdot \mu \mathrm{M}^{-1} \cdot \mathrm{s}^{-1}$ and to singly bind ten receptors would require an oN rate of only $4 \cdot \mu \mathrm{M}^{-1} \cdot \mathrm{s}^{-1}$. If, more conservatively, we assume a 10-fold lower receptor density (500/ $\mu \mathrm{m}^{2}$ ), then binding of 10 receptors singly or doubly would require respective oN rates of $\sim 40$ and $60 \cdot \mu \mathrm{M}^{-1} \cdot \mathrm{s}^{-1}$. Moreover, even at these on rates, some receptors beyond

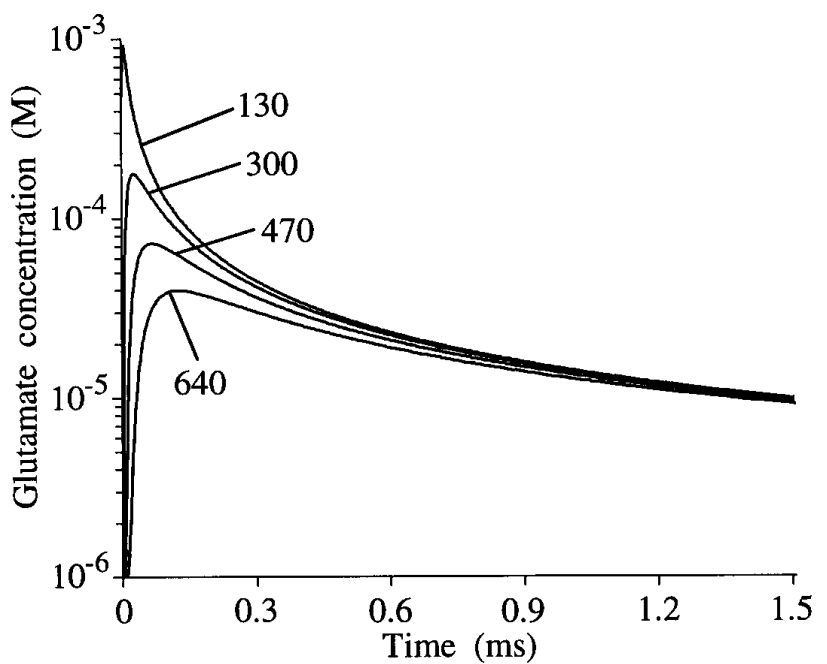

FIG. 4. Glutamate concentration from 1 vesicle discharge peaks lower at bipolar cell receptors and falls slowly. Peak glutamate concentrations at the mGluR6 receptors due to release sites located 130-640 $\mathrm{nm}$ away reach $\geq 30 \mu \mathrm{M}$ and remain above the bipolar cell receptor $\mathrm{EC}_{50}(10 \mu \mathrm{M})$ for $\sim 1$ $\mathrm{ms}$. 
the patch also would see glutamate concentrations high enough for binding.

These calculated on rates for the horizontal cell and bipolar cell receptors $\left(4-60 \cdot \mu \mathrm{M}^{-1} \cdot \mathrm{s}^{-1}\right)$ are quite plausible. They are well below diffusion-limited rates (100-
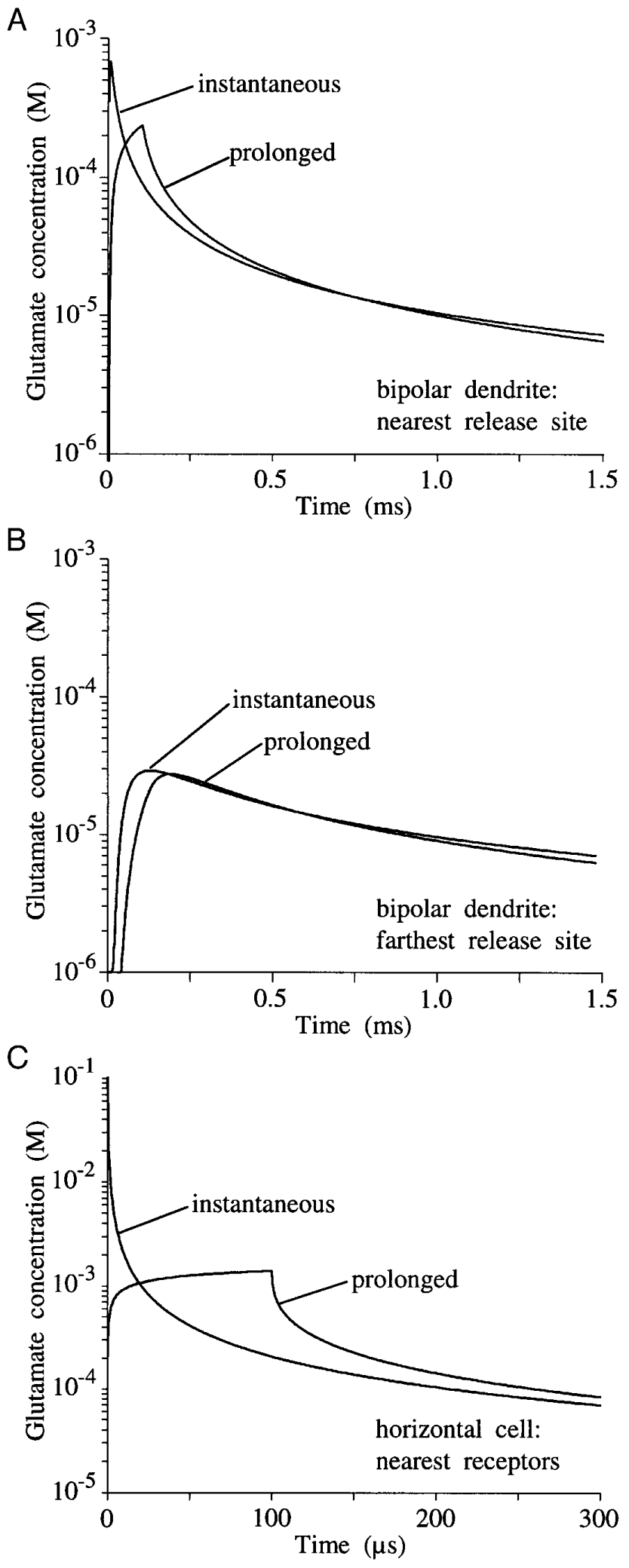

$\left.1,000 \cdot \mu \mathrm{M}^{-1} \cdot \mathrm{s}^{-1}\right)($ Clements and Westbrook 1991), and they match the range of ON rates estimated for AMPA and $N$ methyl-D-aspartate receptors $\left(5-50 \cdot \mu \mathrm{M}^{-1} \cdot \mathrm{s}^{-1}\right)$ (Clements and Westbrook 1991; Holmes 1995; Jonas et al. 1993; Raman and Trussell 1995).

Thus even though about three-fourths of the glutamate molecules diffuse uselessly out the arms of the Y-shaped cleft and some are bound by the horizontal cells, the remaining molecules in the stem of the cleft could establish a spatiotemporal concentration at the bipolar dendrites ample to bind enough mGluR6 receptors for a quantal PSP. If glutamate molecules were lost to the stem due to singlebinding by additional AMPA receptors ( say by half the sites that see concentrations $>0.5 \mathrm{mM}$ ), then peak [glutamate $]_{\text {cleft }}$ at the bipolar receptors due to release from the farthest site drops to $\sim 25 \mu \mathrm{M}$. However, the change in temporal profile is negligible, so binding 10 mGluR6 receptors would require the same on rates. In short, because mGluR6 has high affinity, glutamate discharged from one vesicle can be effective even from a relatively great distance.

\section{Effect of real time discharge from a vesicle}

We initially treated vesicle release as an instantaneous point source (Figs. 3 and 4). More realistic discharge over $100 \mu \mathrm{s}$ (Almers and Tse 1990) was modeled using the instantaneous release of $1 / 100$ th of the point source strength every $1 \mu \mathrm{s}$ for $100 \mu \mathrm{s}$. This prolonged discharge lowers the peak concentration and delays the time to peak (Fig. 5). However, the temporal profiles still converge in $<300 \mu$ s. Thus whether vesicle emptying is instantaneous or prolonged matters little for receptor binding at the distant bipolar dendrites (Fig. 5, $A$ and $B$ ). Horizontal cell receptors directly across from the release site would see the greatest difference (Fig. $5 C$ ), but concentrations would still peak above the $\mathrm{EC}_{50}$, and the slower time course should actually enhance receptor binding.

\section{Release rate needed for integration within the dendrites}

Previously we calculated the minimum release rate to transfer the single photon signal to be 40 vesicles/s (Rao et al. 1994). This assumed simply that the rod's signal/noise ratio $(\sim 5)$ is preserved in the bipolar cell. But if release is stochastic, there is another constraint. False positive signals ("dark events") would arise when an "extra-long" interval between successive PSPs allows the bipolar cell to depolarize past its threshold for signaling to the next stage. Dark events from this source must occur less frequently than those due to the thermal isomerization of rhodopsin because the

FIG. 5. Real time discharge over $100 \mu$ s lowers the peak concentration and delays the time to peak. $A$ and $B$ : glutamate concentration at the bipolar dendrites due to instantaneous and prolonged $(100 \mu \mathrm{s})$ release at the nearest release site $(A)$ and the farthest release site $(B)$ : both models of release produce concentrations that remain above the bipolar cell receptor $\mathrm{EC}_{50}$ (10 $\mu \mathrm{M}$ ) for $\sim 1 \mathrm{~ms}$, so postsynaptic receptor binding should be identical. $C$ : glutamate concentrations at the horizontal cell receptors directly across from the release site due to instantaneous and prolonged ( $100 \mu$ s $)$ release: prolonged release produces concentrations that peak above the horizontal cell receptor $\mathrm{EC}_{50}(0.5 \mathrm{mM})$ and remain there for longer times than concentrations due to instantaneous release; thus if anything, receptor binding should be enhanced. 


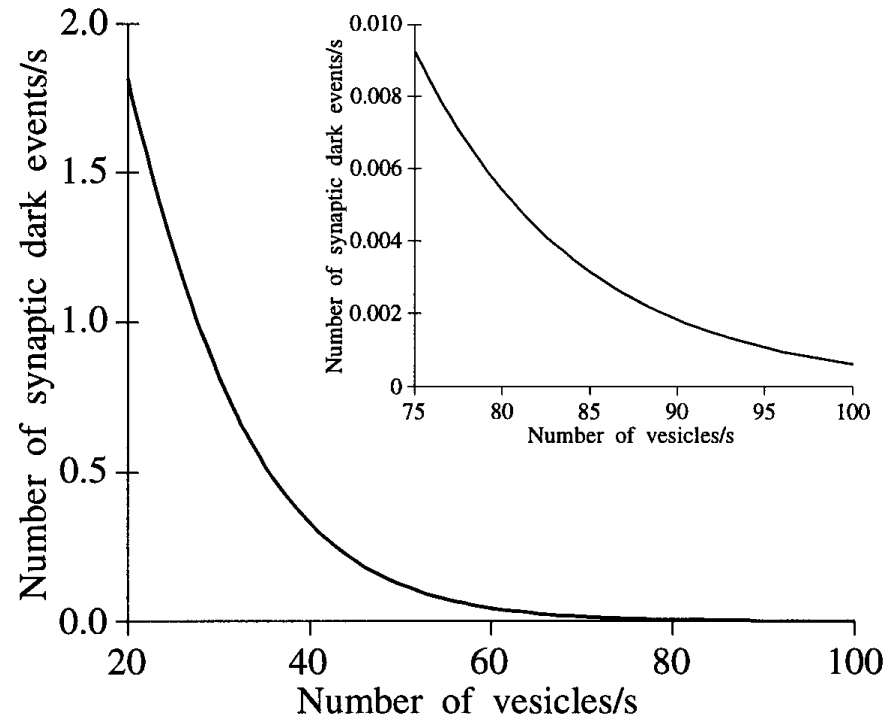

FIG. 6. Rate of synaptic dark events falls with increasing vesicle release rate. Synaptic dark events greatly exceed the thermal rate at 40 vesicles/s but fall to $10 \%$ of the thermal rate at 100 vesicles/s. Inset: expansion of plot between $75-100$ vesicles/s.

latter apparently dominates the ganglion cell's spontaneous discharge in the dark (Barlow et al. 1971; see also Sterling et al. 1988). Therefore we calculated what rate of vesicle release would hold the rate of synaptic dark events (i.e., those due to extra-long intervals) to a small percentage $(10 \%)$ of the thermal rate.

We take the probability of a dark event as the probability that an interval between transmitter quanta is long enough for the bipolar cell voltage to cross threshold (Rao et al. 1994). This is the probability that a PSP peaks and decays to half the signal amplitude due to a photon. We estimate this interval to be $\sim 120 \mathrm{~ms}$ ( see Fig. $2 \mathrm{~A}$ in Rao et al. 1994). Because the probability of release per release site is low due to the large number of release sites at the rod active zone, we model release as a Poisson process. Consequently, the distribution of interrelease intervals is exponential, and a specific release rate gives a probability of intervals $>120$ ms of $e^{- \text {(release rate } \times 120 \mathrm{~ms})}$ (see Eqs. 2 and 3 and Fig. 2C in Rao et al. 1994). Thus

$$
\text { rate of synaptic dark events }=\text { release rate } \times e^{- \text {release rate } \times 120 \mathrm{~ms}}
$$

Thus a release rate of 40 vesicles/s gives a rate of synaptic dark events of $0.33 / \mathrm{s}$. This synaptic dark rate is 50 -fold higher than the thermal dark rate $(0.0063 / \mathrm{s}$ ) (Baylor et al. 1984). But at 79 vesicles/s, the two dark rates are approximately equal and at 100 vesicles/s the synaptic dark rate is down to $10 \%$ of the thermal rate (Fig. 6). Thus integration within the bipolar dendrites would require a release rate of $\sim 100$ vesicles/s. This agrees with a calculation by van Rossum and Smith (1998) using a different model.

\section{IS CUSSION}

\section{Diffusion can deplete the invagination rapidly}

The mammalian rod's synaptic invagination is deepest and most elaborate of any known retinal synapse. By comparison the invagination of the salamander rod and the mam- malian cone are shallow (Calkins et al. 1996; Lasansky 1973 ). Therefore, if any invagination retards passive efflux of transmitter (Eccles and Jaeger 1958; Eliasof and Werblin 1993 ), this should be the one. Yet according to our calculations, one quantum would diffuse from the invagination with a time constant of $1.7 \mathrm{~ms}$.

Conceivably, diffusion through the synaptic cleft could be retarded by a meshwork of macromolecules or by the tortuous path created by the invaginating processes (cf. Fig. $1, C$ vs. $A$ ). A lower diffusion coefficient would reduce the release rate needed for integration within the cleft. However, to reduce the rate to 100 vesicles/s, $D$ would have to drop by 40 -fold. Tortuosity reduces the diffusion coefficient by $\leq 2$.4-fold measured over long distances $(>40 \mu \mathrm{m})$ and long times ( $>100 \mathrm{~s}$ ) (Nicholson and Phillips 1981). Thus if tortuosity plays some role in the rod terminal, it would not affect our conclusions. Moreover, because a decrease in $D$ would extend the temporal concentration profiles produced by one quantum, each release would be even more likely to cause a PSP, thus strengthening the second model ( "integration within the dendrite"').

\section{Maximum tonic release rate}

The two hypotheses considered here, integration within the cleft and integration within the dendrite predict 40 -fold different rates of tonic exocytosis: 4,000 versus 100 vesicles $\cdot$ ribbon $^{-1} \cdot \mathrm{s}^{-1}$. Which rate, if either, is plausible?

Cone synapses in the intact turtle retina tonically bombard an OFF bipolar cell in darkness with $\sim 9,200$ " transmitterrelated events" per second (noise analysis). This suggests, given an estimated convergence of 125-500 ribbon synapses, a rate of $20-80$ vesicles $\cdot$ ribbon $^{-1} \cdot \mathrm{s}^{-1}$ (Ashmore and Copenhagen 1983). Similarly, bipolar synapses in the intact cat retina contribute a sustained input to the beta ganglion cell of 4,500 events/s (noise analysis). This suggests, given the known convergence of 150 ribbon synapses (Cohen and Sterling 1992; Kier et al. 1995 ), a rate of $\sim 30$ vesicles $\cdot$ ribbon $^{-1} \cdot \mathrm{s}^{-1}$ (M. Freed, unpublished observations ). However, because half of these synapses operate tonically at 1 vesicle $\cdot$ ribbon $^{-1} \cdot \mathrm{s}^{-1}(\mathrm{M}$. Freed, unpublished observations), the tonic rate for some bipolar synapses may reach 50 vesicles $\cdot$ ribbon ${ }^{-1} \cdot \mathrm{s}^{-1}$. Finally, an isolated salamander rod fuses $\sim 35 \mathrm{f} \mathrm{F} / \mathrm{s}$ of membrane in response to small jumps in intracellular calcium. This suggests exocytosis of 400 vesicles/s for the whole terminal (Rieke and Schwartz 1996) and, given 8 ribbons/terminal (Townes-Anderson et al. 1985), a rate of 50 vesicles $\cdot$ ribbon $^{-1} \cdot \mathrm{s}^{-1}$. Thus both noise analysis and capacitance measurements coupled with anatomic measurements of the number of ribbons suggest tonic release rates within 100 vesicles $\cdot$ ribbon $^{-1} \cdot \mathrm{s}^{-1}$.

However, a ribbon synapse, responding to maximal calcium current, can release $\leq 500$ vesicles/s. This peak rate was determined by capacitance measurements on the isolated bipolar terminal (von Gersdorff et al. 1996) and also on the isolated saccular hair cell (Parsons et al. 1994). This peak rate falls well short of the 4,000/s required for integration within the cleft; furthermore the bipolar synapse sustains this rate for only $\sim 200 \mathrm{~ms}$ before exhausting its readily releasable pool (von Gersdorff and Matthews 1994; von Gersdorff et al. 1996). 
The ready pool at the bipolar cell synapse corresponds to the depot of vesicles tethered to the ribbon $(\sim 100$ vesicles $)$ (see von Gersdorff et al. 1996). If this is also true at the mammalian rod, then its about sixfold larger ribbon (Fig. $1 B$ ) might release 500 vesicles/s for $>1 \mathrm{~s}$ but clearly not for minutes let alone the hours required for the rod's tonic release at night. In summary, the tonic rate calculated as essential for integration within the cleft is 40 -fold higher than the tonic rates measured at several types of ribbon synapse. But the tonic rate calculated as essential for integration within the dendrite corresponds closely to the measured rates.

\section{Why does the light response require glutamate transporters?}

Before discarding the idea that glutamate is sensed as a concentration, one needs to explain why blocking the glutamate transporter rapidly abolishes the horizontal cell's light response (Eliasof and Werblin 1993; Vandenbranden et al. 1996). In our calculations, glutamate concentration is low outside the invagination providing the gradient needed to flush glutamate passively from the invagination. If transporters were blocked, then rapid binding to the transporters soon would saturate (Wadiche et al. 1995), and glutamate outside the invagination would rise, especially because neighboring rod terminals also contribute. The gradient would decline rapidly, so $C_{\text {invag }}$ would rise. Even conventional synapses releasing quanta at far lower rates require transporter activity to prevent "spillover" between neighbors (Asztely et al. 1997). So blocking transporters at the rod terminal should abolish transmission even if the transporter merely scavenges glutamate at the mouth of the invagination rather than from deep inside.

Recently, immunoreactivity for the glutamate transporter, GLT1, has been observed in the tips of rabbit rod bipolar dendrites, i.e., within the invagination (S. Massey, private communication). If this transporter was comparable to the mGluR6 receptor in affinity, kinetics, and spatial density, it would compete with the receptor for glutamate. This would oppose the effect of vesicular release and require the quantal rate to maintain a steady glutamate concentration to be even higher than we have calculated (integration within the cleft). If GLT1's unbinding and transport are slow, as they are for other glutamate transporters (see Diamond and Jahr 1997; Rusakov and Kullman 1998; Wadiche et al. 1995), GLT1 would little effect the rapid rise and early decay of the glutamate puff (integration within the dendrite). It might reduce the puff's peak amplitude, but this effect cannot be calculated because the distribution of transporters is unknown. A probable effect of the transporter would be to suppress the puff's long tail and thus sharpen the gradient for diffusion. This suppression resembles the effect of the GABA transporter at the cerebellar glomerular synapse (Rossi and Hamann 1998).

\section{One quantum, four PSPS}

Our model of diffusion in the rod synaptic geometry suggests that one transmitter quantum can evoke a discrete PSP at multiple second-order neurons. Although only two bipolar dendrites invaginate the cat rod terminal (Rao-Mirotznik et al. 1995; Sterling et al. 1988), there can be up to seven bipolar dendrites in primates (Grünert and Martin 1991; Missotten 1965). However, the quantum is not the same for all processes.

Near the release site, horizontal cell spines see it as a sharp pulse: concentrated, localized, and brief (Fig. $3 B$ ), like that of many glutamatergic, central synapses (Clements 1996; Clements et al. 1992; Diamond and Jahr 1997). The linear active zone is quite long, extending for 2,300 nm. But the receptor sheet on the horizontal cell spine extends parallel to it (Figs. $1 B$ and $2 B$ ), so wherever the quantum arises along the linear active zone, a small patch of AMPA receptors always sees it as a sharp pulse. The binding properties of these receptors (low affinity, fast dissociation) match the temporal concentration of the pulse and should, we calculate, allow $\sim 10$ receptors to be doubly bound. Because the glutamate pulse would not saturate the whole receptor sheet, PSP amplitudes would fluctuate with quantal content and receptor binding. But the horizontal cell integrates tonic bombardment from $>1,000$ rods and is coupled electrically to its neighbors (Vaney 1993; Wässle et al. 1978), so fluctuations in PSP amplitude should be greatly averaged.

Far from the release site, bipolar dendrites see the glutamate quantum as a weaker "puff": more dilute, diffuse, and prolonged (Fig. 4). The active zone is arched, a highly conserved feature that sets all release sites roughly equidistant to the center of the invagination (Fig. 1B). Consequently, no matter where along the arch a quantum is released, the patch of mGluR6 receptors on the invaginating bipolar dendrites (Nomura et al. 1994; Vardi and Morigiwa 1997) always sees roughly the same puff.

The binding properties of these receptors (high affinity, probably slow dissociation), match the puff 's temporal concentration. Although it may not saturate these receptors, only a few need bind to close all the cGMP-gated cation channels at the dendritic tip (de la Villa et al. 1995). Because these channels have a high open probability (de la Villa et al. 1995), when the puff arrives, the evoked mini-PSP should be all or none (all channels open $\rightarrow$ all closed). Thus it is less intrinsically noisy than the PSP evoked by the same quantum at the horizontal cell. This may be critical to the rod bipolar cell's function because channel fluctuation would degrade the cell's ability to detect the few "missing" transmitter quanta suppressed by a photoisomerization in one rod among the stochastic barrage of quanta from all 20 rods.

\section{Why the rod synapse is three dimensional}

A synapse where one quantum affects many postsynaptic processes conserves both energy and space, and space is known to be a constraint (Hsu et al. 1998). Furthermore this arrangement, by copying the identical message to multiple rod bipolar processes, improves transmission to the next stage. But why not implement this circuit in two dimensions, for example, by arranging postsynaptic processes concentrically across a standard cleft?

This design would cause spillover of transmitter that would functionally couple adjacent rods. Coupling, because it pools the continuous dark noise from many rods, degrades transmission of the binary signal (Smith et al. 1986). Spill- 
over does occur at central synapses where conventional active zones lie within a micrometer of each other (Asztely et al. 1997; Faber and Korn 1988; Otis et al. 1996; Rossi and Hamann 1998; Trussell et al. 1993). A synapse can minimize spillover by using large numbers of transporter molecules to bind glutamate rapidly (Otis et al. 1997). But this strategy would tend to prevent a quantum from reaching multiple processes. The three-dimensional design (deep invagination) allows one quantum to serve multiple processes while preventing coupling of neighboring rods by spillover.

In summary, conventional transmission of the rod's binary signal (integration of discrete PSPs within the bipolar dendrite) fits several related observations: stochastic models predict a modest quantal rate, this rate matches measured tonic rates, and the conventional mechanism explains several highly conserved aspects of the synaptic architecture, such as why the active zone is arched, why AMPA receptors are near and mGluR6 receptors are far from the release sites, and why the cleft is three dimensional. The most obvious test of this model would be to see if mini-PSPs can be observed in whole cell recordings from the rod bipolar cell. This recently has been achieved for ofF bipolar cells (DeVries and Schwartz 1997); thus it might be technically feasible for rod bipolar cells.

We are grateful to S. Shrom for technical assistance and S. Fina for preparing the manuscript. We also thank M. Wilson, S. Schein, and E. Stanley for comments on the manuscript and N. Vardi and R. Smith for helpful discussions.

This work was supported by National Eye Institute Grant EY-00828.

Present address of R. Rao-Mirotznik: Synaptic Mechanisms Section, NINDS, NIH, 36/5A16, 9000 Rockville Pike, Bethesda, MD 20892.

Address for reprint requests: P. Sterling, 123 Anatomy-Chemistry Bldg, Dept. Neuroscience, University of Pennsylvania, Philadelphia, PA 191046058.

Received 16 April 1998; accepted in final form 27 August 1998.

\section{REFERENCES}

Almers, W., Breckenridge, L. A., And Spruce, A. E. The mechanism of exocytosis during secretion in mast cells. In: Secretion and Its Control, edited by G. S. Oxford and C. M. Armstrong. New York: Rockefeller University Press, 1989 , p. 269-282.

Almers, W. AND Tse, F. W. Transmitter release from synapses: does a preassembled fusion pore initiate exocytosis? Neuron 4: 813-818, 1990.

Ashmore, J. F. AND Copenhagen, D. An analysis of transmission from cones to hyperpolarizing bipolar cells in the retina of the turtle. J. Physiol. (Lond.) 340: 569-597, 1983.

AsHMORE, J. F. AND FALK, G. Responses of rod bipolar cells in the darkadapted retina of the dogfish. Scyliorhinus canicula. J. Physiol. (Lond.) 300: 115-150, 1980.

Asztely, F., ERdemli, G., And Kullmann, D. M. Extrasynaptic glutamate spillover in the hippocampus: dependence on temperature and the role of active glutamate uptake. Neuron 18: 281-293, 1997.

Barlow, H. B., Levick, W. R., AND Yoon, M. Responses to single quanta of light in retinal ganglion cells of the cat. Vision Res. S3: 87-101, 1971.

BAYLOR, D. A., NunN, B. J., AND SChNAPF, J. L. The photocurrent, noise and spectral sensitivity of rods of the monkey Macaca fascicularis. $J$. Physiol. (Lond.) 357: 575-607, 1984.

Burger, P. M., Mehl, E., Cameron, P. L., Maycox, P. R., Baumert, M., Lottspeich, F., de Camilli, P., And Jahn, R. Synaptic vesicles immunoisolated from rat cerebral cortex contain high levels of glutamate. Neuron 3: 715-720, 1989.

CAlkins, D. J., Tsukamoto, Y., AND Sterling, P. Foveal cones form basal as well as invaginating junctions with diffuse ON bipolar cells. Vision Res. 36: 3373-3381, 1996.

Clements, J. D. Transmitter time course in the synaptic cleft: its role in central synaptic function. Trends Neurosci. 19: 163-171, 1996.
Clements, J. D., Lester, R.A.J., Tong, G., Jahr, C. E., And Westbrook, G. L. The time course of glutamate in the synaptic cleft. Science 258: 1498-1501, 1992.

Clements, J. D. and Westbrook, G. L. Activation kinetics reveal the number of glutamate and glycine binding sites on the $N$-methyl-D-aspartate receptor. Neuron 7: 605-613, 1991.

CoHen, E. AND STerling, P. Parallel circuits from cones to the on-beta ganglion cell. Eur. J. Neurosci. 4: 506-520, 1992.

Crank, J. The Mathematics of Diffusion. New York: Oxford, 1990.

De la Villa, P., Kurahashi, T., and KaneKo, A. L-glutamate-induced responses and cGMP-activated channels in three subtypes of retinal bipolar cells dissociated from the cat. J. Neurosci. 15: 3571-3582, 1995.

DeVries, S. H. AND Schwartz, E. A. Mechanism of communication at the cone basal synapse. Soc. Neurosci. Abstr. 23: 578, 1997.

DiAMOND, J. S. AND JAHR, C. E. Transporters buffer synaptically released glutamate on a submillisecond time scale. J. Neurosci. 17: 4672-4687, 1997.

Dowling, J. E. The Retina: An Approachabale Part of the Brain. Cambridge MA: Belknap Press, 1987.

Dowling, J. E. AND BoycotT, B. B. Organization of the primate retina: electron microscopy. Proc. R. Soc. Lond. B Biol. Sci. 166: 80-111, 1966.

ECCLES, J. C. AND JAEGER, J. C. The relationship between the mode of operation and the dimensions of the junctional regions at synapses and motor end-organs. Proc. R. Soc. Lond. B Biol. Sci. 146: 38-56, 1958.

Edwards, F. A., KonNerth, A., AND SAKMAnN, B. Quantal analysis of inhibitary synaptic transmission in dentate gyrus of rat hippocampal slices: a patch clamp study. J. Physiol. (Lond.) 430: 213-249, 1990.

ELIASOF, S. AND JAHR, C. E. Rapid AMPA receptor desensitization in catfish cone horizontal cells. Vis. Neurosci. 14: 13-18, 1997.

Eliasof, S. AND Werblin, F. Characterization of the glutamate transporter in retinal cones of the tiger salamander. J. Neurosci. 13: 402-411, 1993.

FABER, D. S. AND KoRN, H. Synergism at central synapses due to lateral diffusion of transmitter. Proc. Natl. Acad. Sci. USA 85: 8708-8712, 1988.

Forti, L., Bossi, M., Bergamaschi, A., Villa, A., And Malgaroli, A. Loose-patch recordings of single quanta at individual hippocampal synapses. Nature 388: 874-878, 1997.

Frerking, M., Borges, S., AND WiLson, M. Variation in GABA mini amplitude is the consequence of variation in transmitter concentration. Neuron 15: 885-895, 1995.

GRUNERT, U. AND MARTIN, P. R. Rod bipolar cells in the Macaque monkey retina: immunoreactivity and connectivity. J. Neurosci. 11: 2742-2758, 1991.

HESTRIN, S. Activation and desensitization of glutamate-activated channels mediating fast excitatory synaptic currents in the visual cortex. Neuron 9: 991-999, 1992.

HiLle, B. Ionic Channels of Excitable Membranes. Sunderland, MA: Sinauer, 1992.

Holmes, W. R. Modeling the effect of glutamate diffusion and uptake on NMDA and non-NMDA receptor saturation. Biophys. J. 69: 1734-1747, 1995.

Hsu, A., Tsukamoto, Y., Smith, T. F., And Sterling, P. Functional architecture of primate rod and cone axons. Vis. Neurosci. 38: 2539-2549, 1998.

Jonas, P., Major, G., And SAKMAnN, B. Quantal components of unitary epscs at the mossy fibre synapse on CA3 pyramidal cells of rat hippocampus. J. Physiol. (Lond.) 472: 615-663, 1993.

Karwoski, R., Karwoski, C. J., Frambach, D. A., and Proenza, L. M. Laminar profile of resistivity in frog retina. J. Neurophysiol. 54: 16071619, 1984.

Kier, C. K., Buchsbaum, G., and Sterling, P. How retinal microcircuits scale for ganglion cells of different size. J. Neurosci. 15: 7673-7683, 1995.

Krizaj, D., Akopian, A., AND Witkovsky, P. The effects of L-glutamate, AMPA, quisqualate, and kainate on retinal horizontal cells depend on adaptational state: implications for rod-cone interactions. J. Neurosci. 14: $5661-5671,1994$.

LASANSKY, A. Organization of the outer synaptic layer in the retina of the larval tiger salamander. Philos. Trans. R. Soc. Lond. B Biol. Sci. 265: 471-489, 1973.

LONGSworth, L. G. Diffusion measurements at 25 degrees, of aqueous solutions of amino acids, peptides and sugars. J. Am Chem. Soc. 75: 5705-5709, 1953. 
Missotten, L. The Ultrastructure of the Human Retina. Brussels: Editions Arscia S. A., 1965

Morigiwa, K. AND VARDI, N. Differential expression of ionotropic glutamate receptor subunits in the outer retina. J. Comp. Neurol. In press.

NAWY, S. AND JAHR, C. E. Suppression by glutamate of cGMP-activated conductance in retinal bipolar cells. Nature 346: 269-271, 1990.

Nicholls, D. AND ATTWELl, D. The release and uptake of excitatory amino acids. Trends Pharmacol. Sci. 11: 462-468, 1990.

Nicholson, C. AND Phillips, J. M. Ion diffusion modified by tortuoisty and volume fraction in the extracellular microenvironment of the rat cerebellum. J. Physiol. (Lond.) 321: 225-257, 1981.

Nomura, A., Shigemoto, R., Nakamura, Y., OKamoto, N., Mizuno, N., AND NAKANISHI, S. Developmentally-regulated postsynpatic localization of a metabotropic glutamate-receptor in rat rod bipolar cells. Cell 77: 361-369, 1994.

Otis, T. S., Kavanaugh, M. P., and Jahr, C. E. Postsynaptic glutamate transport at the climbing fiber - Purkinje cell synapse. Science 277: 15151518, 1997.

OTIS, T. S., Wu, Y.-C., AND TRussell, L. O. Delayed clearance of transmitter and the role of glutamate transporters at synapses with multiple release sites. J. Neurosci. 16: 1634-1644, 1996.

Parsons, T. D., Lenzi, D., Almers, W., and Roberts, W. M. Calciumtriggered exocytosis and endocytosis in an isolated presynaptic cell: capacitance measurements in saccular hair cells. Neuron 13: 875-883, 1994.

Patneau, D. K. And Mayer, M. L. Structure-activity relationships for amino acid transmitter candidates acting as $N$-methyl-D-aspartate and quisqualate receptors. J. Neursoci. 10: 2385-2399, 1990.

RAMAN, I. M. AND TRUSSELL, L. O. The mechanism of $\alpha$-amino-3-hydroxy5-methyl-4-isoxazolepropionate receptor desensitization after removal of glutamate. Biophys. J. 68: 137-146, 1995.

RaO, R., Buchsbaum, G., and Sterling, P. Rate of quantal transmitter release at the mammalian rod synapse. Biophys. J. 67: 57-63, 1994.

Rao-Mirotznik, R., Harkins, A. B., Buchsbaum, G., and Sterling, P. Mammalian rod terminal: architecture of a binary synapse. Neuron 14: 561-569, 1995.

RAVIOLA, E. AND GILULA, N. B. Intramembrane organization of specialized contacts in the outer plexiform layer of the retina. J. Cell Biol. 65: 192222, 1975.

RIEKE, F. AND Schwartz, E. A. Asynchronous transmitter release: control of exocytosis and endoxytosis at the salamander rod synapse. J. Physiol. (Lond.) 493: 1-8, 1996.

Riveros, N., Fiedler, J., Lagos, N., Muñoz, C., ANd OrRego, F. Glutamate in rat brain cortex synaptic vesicles: influence of the vesicle isolation procedure. Brain Res. 386: 405-408, 1986.

Rossi, D. J. AND HamanN, M. Spillover-mediated transmission at inhibitory synapses promoted by high affinity $\alpha_{6}$ subunit $\mathrm{GABA}_{\mathrm{A}}$ receptors and glomerular geometry. Neuron 20: 783-795, 1998.

RsuaKov, D. A. AND Kullmann, D. M. Extrasynaptic glutamate diffusion in the hippocampus: ultrastructural constraints, uptake, and receptor activation. J. Neurosci. 18: 3158-3170, 1998.

SHIELls, F. A. AND FALK, G. Glutamate receptors of rod bipolar cells are linked to a cyclic GMP cascade via a G-protein. Proc. R. Soc. Lond. B Biol. Sci. 242: 91-94, 1990.
ShIELls, R. A. AND FALK, G. Responses of rod bipolar cells isolated from dogfish retinal slices to concentration-jumps of glutamate. Vis. Neursoci. 11: $1175-1183,1994$.

Smith, R. G., Freed, M. A., AND Sterling, P. Microcircuitry of the darkadapted cat retina: functional architecture of the rod-cone network. $J$. Neurosci. 6: 3505-3517, 1986.

STERLING, P. Retina. In: The Synaptic Organization of the Brain, edited by G. M. Shepherd. New York: Oxford University Press, 1998, p. 205-253.

Sterling, P., Freed, M. A., AND Smith, R. G. Architecture of the rod and cone circuits to the On-beta ganglion cell. J. Neursoci. 8: 623-642, 1988.

Stern, P., Edwards, F. A., AND SAKmann, B. Fast and slow components of unitary epscs on stellate cells elicited by focal stimulation in slices of rat visual cortex. J. Physiol. (Lond.) 449: 247-278, 1992.

Tian, N. AND SLAughter, M. M. Pharmacological similarity between the retinal APB receptor and the family of metabotropic glutamate receptors. J. Neurophysiol. 71: 2258-2268, 1994.

Townes-Anderson, E. MacLeish, P. R., and Raviola, E. Rod cells dissociated from mature salamander retina: ultrastructure and uptake of horseradish peroxidase. J. Cell Biol. 100: 175-188, 1985.

Traynelis, S. F., Silver, R. A., AND Cull-Candy, S. Estimated conductance of glutamate receptor channels activated during epsc's at the cerebellar mossy fiber-granule cell synapse. Neuron 11: 279-289, 1993.

Trussell, L. O. AND FischBACH, G. D. Glutamate receptor desensitization and its role in synaptic transmission. Neuron 3: 209-218, 1989.

Trussell, L. O., Zhang, S., and Raman, I. M. Desensitization of AMPA receptors upon multiquantal neurotransmitter release. Neuron 10: 11851196, 1993.

van Rossum, M.C.W. AND SMIth, R. G. Noise removal at the rod synapse. Vis. Neurosci. 15: 809-821, 1998.

Vandenbranden, C.A.V., Verweis, J. Kameermans, M., Müller, L. J., Ruijter, J. M., Vrensen, G.F.J.M., and Spekreisse, H. Clearance of neurotransmitter from the cone synaptic cleft in goldfish retina. Vision Res. 36: 3859-3874, 1996.

VANEY, D. I. The coupling pattern of axon-bearing horizontal cells in the mammalian retina. Proc. R. Soc. Lond. B Biol. Sci. 252: 93-101, 1993.

VARDI, N. AND Morigiwa, K. ON cone bipolar cells in rat express the metabotropic receptor mGluR6. Vis. Neurosci. 14: 789-794, 1997.

von Gersdorff, H. and Matthews, G. Dynamics of synaptic vesicle fusion and membrane retrieval in synaptic terminals. Nature 367: 735739, 1994.

von Gersdorff, H., VArdi, E., Matthews, G., AND Sterling, P. Evidence that vesicles on the synaptic ribbon of retinal bipolar neurons can be rapidly released. Neuron 16: 1-20, 1996.

Wadiche, J. I., Arriza, J. L., Amara, S. G., and Kavanaugh, M. P. Kinetics of a human glutamate transporter. Neuron 14: 1019-1927, 1995.

Wahl, L. M., Pouzat, C., AND StratFord, K. J. Monte Carlo simulation of fast excitatory synaptic transmission at a hippocampal synapse. $J$. Neurophysiol. 75: 597-608, 1996.

Wässle, H., Boycott, B. B., AND Peichl, L. Receptor contacts of horizontal cells in the retina of the domestic cat. Proc. R. Soc. Lond. B Biol. Sci. 203: 247-267, 1978.

WiLsOn, J. AND Karwoski. C. J. First International Workshop on Müller cells, Leipzig, 1995. 